\title{
Congenital lacrimal obstruction: case series of probing and intubation
}

\author{
Obstrução congênita de vias lacrimais: \\ série de casos de sondagem e intubação
}

Adriana Pires Smaniotto¹, Caio Cézar Gazim¹, Hamilton Moreira², Rodrigo Beraldi Kormann², Virgínia Lúcia Bezerra²

\begin{abstract}
Objective: To evaluate the relationship between age at surgery in patients with congenital lacrimal obstruction and success achieved by them. Methods: We studied 94 medical records of patients diagnosed with congenital lacrimal obstructions, assisted at the oculoplastic sector of the Hospital de Olhos do Paraná, in the period january 2006 to december 2012. For diagnosis and inclusion in the study, the clinical history were made, overall and specific ophthalmologic examination, with the tests: Milder and Observation Test of Fluorescein in the Oropharynx. To determine the type of intervention (probing or intubation) service criteria were used. In the statistical analysis, the chi-square and Student's t test were used. Significance level of $5 \%$ was adopted. Results: When comparing the results by age, regardless of treatment, there was no significant association $(p=0.223)$ between the rate of improvement and age. Conclusion: In the present study shows, there is no significant difference between the surgical interventions within the age groups addressed.

Keywords: Lacrimal duct obstructions/surgery; Lacrimal duct obstructions/congenital; Congenital anomalies, ; Duct nasolacrimal/ abnormalities
\end{abstract}

\section{ReSUMO}

Objetivo: Avaliar a relação entre a idade da intervenção cirúrgica em pacientes portadores de obstrução congênita das vias lacrimais e o sucesso obtido pelos mesmos. Métodos: Foram estudados 94 prontuários de pacientes com diagnóstico de obstrução congênita de vias lacrimais, assistidos no setor de oculoplástica do Hospital de Olhos do Paraná, no período de janeiro de 2006 a dezembro de 2012. Para diagnóstico e inclusão na pesquisa foram realizados a anamnese, exames oftalmológico geral e específico utilizando o Teste de Milder e o Teste de Obtenção de Fluoresceína na Orofaringe. Para determinar o tipo de intervenção (sondagem ou intubação) foram utilizados os critérios do serviço. Na análise estatística foram utilizados o teste de qui-quadrado e o teste t de Student e adotado o nível de significância de 5\%. Resultados: Quando comparados os resultados por idade, independente do tratamento, não houve associação significativa $(\mathrm{p}=0,223)$ entre a taxa de melhora e a idade. Conclusão: No presente estudo não houve diferença significativa entre a intervenção cirúrgica e as faixas etárias abordadas.

Descritores: Obstrução dos ductos lacrimais/cirurgia; Obstrução dos ductos lacrimais/congênito; Anomalias congênitas; Ducto nasolacrimal/anormalidades

\footnotetext{
${ }^{1}$ Hospital Universitário Evangélico de Curitiba, Curitiba, PR, Brazil.

${ }^{2}$ Hospital de Olhos do Paraná (HOP), Curitiba, PR, Brazil.

Work performed in Hospital de Olhos do Paraná (HOP), Curitiba, PR, Brazil.

The authors declare no conflicts of interests.

Received for publication 06/08/2015 - Accepted for publication 02/09/2015
} 


\section{INTRODUCTION}

$\mathbf{L}$ acrimal pathways obstruction is a common condition in ophthalmologic clinics, representing around $5 \%$ of appointments. ${ }^{(1)}$ The congenital nasolacrimal duct obstruction (CNLDO), among congenital abnormalities affecting the excretory lacrimal pathway, is the most common, accounting for approximately $90 \%$ of obstructions and affecting $5-20 \%$ of newborns. ${ }^{(2-6)}$

The classic condition of congenital obstruction of the lacrimal pathways (COLP) consists of continuous epiphora and mucoid secretion. It is important to stress that the secretion may be apparent only after the expression of the lacrimal sac. A classic sign is wet eye with secretions. ${ }^{(7)}$ In COLP, some conjunctival hyperemia is acceptable, especially in the lower fornix, but usually the conjunctiva is normal (with no hyperemia).(6)

The diagnosis of COLP is made by anamnesis and eye examination, and complementary examinations are used in specific cases. ${ }^{(6-9)}$ For eye examination, the main specific tests are the Milder test or fluorescein dye disappearance test (FDDT) and the observation test of fluorescein in the oropharynx (OTFO). ${ }^{(8)}$

The therapeutic conduct depends mainly on the signs and symptoms and the age of the child. In children under 6 months of age it generally consists of guidance to parents, eye hygiene with mineral water or saline solution $0.9 \%$ and Crigler massage. ${ }^{(8)}$

Antibiotic eyedrops can be used, but they do not work in desobstruction, and are used to decreased secretion, decreasing the infectious component and being prophylactic for dacryocystitis. Its use should be restricted to periods in which the signs are more severe. ${ }^{(10,11)}$

From 6 months to 1 year of age, parents should discuss the surgical treatment, usually the probing of the vias lacrimais ${ }^{(6,8)}$, being it a safe and feasible as an initial procedure. ${ }^{(12)}$ Another surgical intervention may be intubation. The technique consists in probing of the lacrimal pathway and subsequently inserting a silicone tube attached by a metal probe. ${ }^{(13)}$

This study aims at evaluating the conduct in patients with COLP, relating the age of the child to the conduct established and the percentage of improvement of the patients.

\section{Methods}

This is a retrospective study, and 94 medical records of patients diagnosed with COLP and treated at the Department of Oculoplastics of HOP from January 2006 to December 2012 were studied. The following data was collected: age, sex, onset of symptoms, presence of epiphora and/or secretion, eye affected, previous surgery, surgical technique performed, improvement or not of postoperative symptoms, need for new surgery, and comorbidities.

For the diagnosis and inclusion in the study, we performed the anamnesis, the general and specific eye examinations, and the following tests: Milder and OTFO. The first was held by dripping eyedrops with fluorescein in the eye affected and waiting from 3 to 5 minutes. After that, it was analyzed under cobalt light, accepting as obstruction the tests in which after 5 minutes the tear meniscus exceeded 1 milímetro thick, meaning probable obstruction of the lacrimal pathways. The second test was done by dripping eyedrops with fluorescein in the affected eye, and after 30 minutes evidencing it in the oropharynx under cobalt light and with a tongue depressor. The test was positive when there was fluorescein in the oropharynx, being it considered pervious lacrimal pathway. In cases where doubts remain after a detailed anamnesis, a general and a specific eye examinations for lacrimal pathways were made, the decision was for dacryocystography. Patients who did not heve followup after surgery were excluded from the research.

To choose the procedure the following criteria were used: for patients between 6 months and 3 years of age with the absence or minimal secretion and with no history of prior surgical treatment the indication was probing of the lacrimal pathway. If there was abundant secretion, reflux of secretion, compression of the lacrimal sac or history of previous unsuccessful surgery, probling with intubation was indicated. In children above 3 years of age probing with intubation was indicated as the procedure of choice. Both procedures were performed under general anesthesia.

The chi-square test and the Student $t$ test were used in the statistical analysis. The significance level of 5\% (0.05) for the application of the statistical tests was adopted. The data was analyzed with the computer program Statistica v.8.0.

This study was approved by the Research Ethics Committee of the Evangelical Beneficent Society of Curitiba under number 366.367.

\section{ResULTS}

During the period of study, 94 COLP patients were attended, and the follow-up time was an average of 4.1 months, ranging from 0.5 to 15.0 months. 49 (52.1\%) female patients and 45 $(47.9 \%)$ male ones were assessed.

As for the eye, $43(45.7 \%)$ had symptoms in left eye, 34 $(36.2 \%)$ in right eye and $17(18.1 \%)$ in both eyes. And 82 patients $(87.2 \%)$ presented epiphora and secretion, 3 (3.2\%) only secretion and $9(9.6 \%)$ only epiphora.

Seven patients came to the hospital with previous surgery, and six had undergone probing and one intubation. In the second procedure, intubation was performed in all of them.

From the 94 patients, $83(88.3 \%)$ improved the symptoms after the procedure (Table 1). Eleven patients (11.7\%) had no improvement, three lost follow-up and eight were reoperated, and all underwent intubation. The three who were not reoperated had the data from the first procedure assessed, once they were followed-up after surgery, even if not being reoperated. Of patients reoperated, 6 (75\%) improved and two discontinued the follow-up at the hospital, and their data from the second procedure were discarded.

The following comorbidities were found in the study: prematurity in five cases $(5.3 \%)$, down syndrome in two $(2.1 \%)$, and arrhythmia, allergies and hypothyroidism had each one representative $(1.1 \%)$, and the comorbidities were found associated in some cases.

When comparing the results by age, regardless of treatment, there was no significant association $(\mathrm{p}=0.223)$ between the rate of improvement and the age. 
Table 1

\section{Comparison of results with respect to age}

\begin{tabular}{lcccccccc}
\hline Result & \multicolumn{4}{c}{ Age } & \multicolumn{2}{c}{ P value* $^{*}$} \\
\hline & N & Mean & Median & Min Max & $\begin{array}{l}\text { Standard } \\
\text { deviation }\end{array}$ & \\
\cline { 2 - 7 } & & & & & & \\
Improved & 83 & 2.2 & 1.6 & 0.6 & 10.2 & 1.8 & 0,223 \\
$\begin{array}{l}\text { Did not } \\
\text { improve }\end{array}$ & 11 & 1.5 & 1.3 & 0.5 & 4.6 & 1.1 & \\
\hline
\end{tabular}

As for probing, the patients who were probed in the age group of one to three years achieved a greater improvement $(86.11 \%)$ than those who were probed with less than one year $(76.47 \%)$. However, this difference was not significant $(\mathrm{p}=0.445)$ (Table 2).

Table 2

Recommended treatment: probing

\begin{tabular}{lcc}
\hline Result & \multicolumn{2}{c}{ Age group } \\
\hline & $<\mathbf{1}$ year $\mathbf{n}(\%)$ & $\mathbf{1}$ a 3 years $\mathbf{n}(\mathbf{\%})$ \\
\cline { 2 - 3 } Improved & $13(76.47)$ & $31(86.11)$ \\
Did not improve & $4(23.53)$ & $5(13.89)$ \\
\hline Total & $\mathbf{1 7}(\mathbf{1 0 0 )}$ & $\mathbf{3 6}(\mathbf{1 0 0 )}$ \\
\hline
\end{tabular}

As for intubation, patients who were intubated in the age group from one to three years had a greater improvement $(95.45 \%)$ than those who were intubated with more than three years $(94.74 \%)$, also with no statistical correlation $(\mathrm{p}=1)$ (Table 3 ). As for the time that the probe was kept, there was an average of 32.8 days, with a minimum of eight and maximum of 122 days, with a standard deviation of 22.8 .

Table 3

Recommended treatment: Intubation

\begin{tabular}{lcc}
\hline Result & \multicolumn{2}{c}{ Age group } \\
\hline & $\mathbf{1}$ a 3 years $\mathbf{n}(\%)$ & $\geq$ 3years $\mathbf{n ( \% )}$ \\
\cline { 2 - 3 } Improved & $21(95.45)$ & $18(94.74)$ \\
Did not improve & $1(4.55)$ & $1(5.26)$ \\
\hline Total & $\mathbf{2 2 ( 1 0 0 )}$ & $\mathbf{1 9 ( 1 0 0 )}$ \\
\hline
\end{tabular}

\section{Discussion}

The treatment for COLP is a very controversial subject, especially regarding the intervention time. ${ }^{(2)}$

Our study demonstrates that there is no significant difference regarding the incidence in females and males, affecting both sexes in the same proportion, corroborating the literature..$^{(7,8)}$

As for the eye, $81.9 \%$ had symptoms only in one eye, and $18.1 \%$ in both eyes. This finding is consistent with the literature, which was evidenced in the study in São Paulo with $38 \%$ bilateral and $62 \%$ unilateral. ${ }^{(8)}$

Studies show the presence of epiphora in $85 \%$ to $100 \%$ of the patients diagnosed, and the presence of secretion in $56 \%$ to
$64 \%$ of them.(10,14) In high congenital obstruction, epiphora is often the only sign found, but in the low one, the association between epiphora and secretion is common. ${ }^{(7,9)}$ In this study, this association happened in $87.1 \%$ of cases, which speaks in favor of low obstruction of the lacrimal pathway in the nasolacrimal duct. This finding is consistent with the literature, that accounts for $90 \%$ of the existing obstructions. ${ }^{(15)}$

In the study, there were two cases of Down syndrome. Catalano in 1990 refers in his work to the nasolacrimal duct obstruction as a rare finding and probably not related to the syndrome, while Cunha et al. in 1986 report a prevalence of $30 \%$, and Lueder in 2000 referred the nasolacrimal duct obstruction as a frequent occurrence in patients with trisomy 21. ${ }^{(16)}$

In this study the success of the probe was assessed up to one year of age and from 1 to 3 years of age, and intubation from 1 to 3 years and above 3 years of age, demonstrating that there is no relation between the time of surgical intervention and the result of the treatment in this age period assessed. It was believed that the success or not of this surgical technique was mainly related to the age the child would submit to probing of lacrimal pathway. However, studies show that in addition to the child's age at the time of the probing there are some predictive factors of bad prognosis: big mucocele, heavy secretion, presence of hard obstacle when trying to probe, and history of previous unsuccessful surgery. Another cause of failure would be related to the nasal cavity, such as the impossibility of drainage of tears due to the compression of the ostium, such as hypertrophy of the turbinates or adenoids and deviated septum. ${ }^{(3,15)}$

Regarding probing, the success rate was of $76.47 \%$ in children under 1 year, different from the literature in that probing achieved cure rates of 95 to $97 \%$ of children under 1 year. A higher success rate $(86.11 \%)$ was obtained for patients between 1 and 3 years, corroborating other studies in which this success rate was from $73 \%$ to $88.5 \%$. ${ }^{(15)}$ Another study points out that patients operated from 37 months on (above 3 years) succeeded only $42.9 \%$ in probing, but the ones operated before that age had $97.1 \%$ of success. Literature reports that the disappearance of signs after probing starts after 3 weeks, with remission within 6 months. $^{(12)}$

In case of failure in the first probing, cure rates of $55 \%$ were found in the second one. ${ }^{(10)}$ However, intubation can be an option. In this research, from the 11 patients who did not improve, 6 patients were reoperated, all of which were underwent intubation with $75 \%$ of improvement.

In this study, similar success rates of intubation were found between in patients from 1 and 3 years and above 3 years, being the first $95.45 \%$ and the second $94.74 \%$. Like probing, intubation showed no statistical relation between age and the treatment outcome. In other studies, a cure rate from $79 \%$ to $96 \%$ with intubation was found. ${ }^{(14,17)}$ If only probing of the lacrimal system was assessed at any age, a significant difference in the success of the procedure could be found, with better results in younger children (under 3 years) compared to children above 3 years of age, according to the literature.

The tube was removed an average of 32.8 days after the procedure, which differs from the literature. Studies support the removal of the tube after at least 2 months, keeping the tube from two to five months. ${ }^{(14)}$ In this study, the choice of time for removing the tube from the lacrimal pathway was based on the improvement of COLP signs 15 days after the child was taking oral or local medication, so from the third week after surgery on. We decided to leave the tube longer in cases of doubt of the 
parents or surgeon regarding the improvement of postoperative signs or in situations where obstructions were higher in the lacrimal pathway during the surgical procedure.

In this study, there were no surgical or anesthetic complications. However, in the literature, there are reports of probing and intubation complications of the lacrimal pathway, as the lacrimal epithelial lesion causing stenosis. There are cases reported of $44 \%$ of stenosis after successive probing, but it is rare when it comes to a single probing. $(6,15)$ There may be damage to the nasal mucosa with significant bleeding, probe impossible to be removed, lesion of the inferior turbinate, tube migration, pyogenic granulomatous formation, cellulitis and abrasion of the cornea and conjunctiva. This can happen during the technique or by the tube that remains outside the lacrimal point. ${ }^{(14,18)}$

\section{Conclusion}

We concluded that there was no significant difference of probing before 1 year or from 1 to 3 years of age, as well as intubation in children from 1 to 3 years and above 3 years of age. The criteria adopted by our service to choose the surgical procedure to be established can be considered adequate when we analyze the results and compare them to the literature.

\section{REFERENCES}

1. Jervásio AC, Melissa R, Zagui B. Implante de ducto nasolacrimal de poliuretano/ : relato de caso. Arq Bras Oftalmol. 2008;71(1):110-4.

2. El-Essawy R. Effect of timing of silicone tube removal on the result of duct intubation in children with congenital nasolacrimal duct obstruction. Ophthal Plast Reconstr Surg. 2013;29(1):48-50.

3. Schellini S, Narikawa S, Ribeiro S, Nakagima V, Padovani CR, Padovani CRP. Obstrução nasolacrimal congênita/ : fatores relacionados com a possibilidade de cura. Arq Bras Oftalmol. 2005;68(2):241-4.

4. MacEwen CJ, Young JD, Barras CW, Ram B, White PS. Value of nasal endoscopy and probing in the diagnosis and management of children with congenital epiphora. $\mathrm{Br} \mathrm{J}$ Ophthalmol. 2001;85(3):314-8.

5. Murillo R, Souza L De, Seronni LB. Dilatação por cateter-balão (dacrioplastia) para tratamento das obstruções congênitas do ducto lacrimonasal. Arq Bras Oftalmol. 2009;72(5):669-72.
6. Young JDH, Macewen CJ. Managing congenital lacrimal obstruction in general practice. BMJ. 1997;315(2):293-6.

7. Schellini SA. Obstrução nasolacrimal congênita - diagnóstico e tratamento. Rev Bras Oftalmol. 2005;64(2):128-32.

8. Lorena SHT, Silva JAF. Estudo retrospectivo da obstrução congênita do ducto lácrimonasal. Rev Bras Oftalmol. 2011;70(2):104-8.

9. Dantas RRA. Lacrimal drainage system obstruction. Semin Ophthalmol. 2010 May;25(3):98-103.

10. Neto ECB, Branco BCB, Cardoso CC, Carvalho RG de C, Mota E, Branco AC. Tratamento das obstruções congênitas do ducto nasolacrimal. Arq Bras Oftalmol. 2009;72(1):17-8.

11. Kushner BJ. Congenital Nasolacrimal System Obstruction. Arch Ophtalmol. 1982;100(4):597-600.

12. Honavar SG, Prakash VE, Rao GN. Outcome of probing for congenital nasolacrimal duct obstruction in older children. Am J Ophthalmol. 2000;130(1):42-8.

13. Fernandes JBVD, Matayoshi S, Komatsu W, Kikuta HS, Moura E da M. Circuito elétrico auxiliar para intubação das vias lacrimais. Arq Bras Oftalmol. 2000;63(5):375-7.

14. Repka MX, Melia BM, Beck RW, Atkinson CS, Chandler DL, Holmes JM, et al. Primary treatment of nasolacrimal duct obstruction with nasolacrimal duct intubation in children younger than 4 years of age. J AAPOS. 2008;12(5):445-50.

15. Schellini S, Narikawa S, Ribeiro S, Nakagima V, Padovani CR, Padovani CRP. Obstrução nasolacrimal congênita/ : fatores relacionados com a melhora após sondagem terapêutica. Arq Bras Oftalmol. 2005;68(5):627-30.

16. Matayoshi S, Sardinha M, Cozac LA, Araf D, Moura E da M. Síndrome de Down e alterações de vias lacrimais. Arq Bras Oftalmol. 2003;66:481-4.

17. Lee H, Ahn J, Lee JM, Park M, Baek S. Clinical effectiveness of monocanalicular and bicanalicular silicone intubation for congenital nasolacrimal duct obstruction. J Craniofac Surg. 2012;23(4):1010-4.

18. Pemberton JD, Miller J, Commander J, Michalos P, Fay A. Electronically assisted nasolacrimal duct silicone intubation. Ophthal Plast Reconstr Surg. 2013;29(1):18-20.

Corresponding author:

Virgínia Lúcia Bezerra

E-mail: virginiabezoftalmo@gmail.com 